\title{
AERIAL MAPPING AND MULTI-SENSORS APPROACHES FROM REMOTE SENSING APPLIED TO THE ROMAN ARCHAEOLOGICAL HERITAGE
}

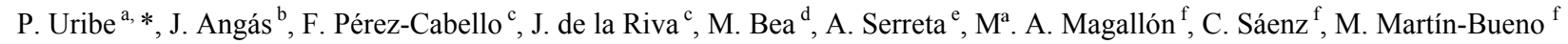 \\ a Tecnitop, Postdoctoral Research Torres Quevedo (MINECO), Zaragoza, Spain - uribe@unizar.es \\ b 3D Scanner Patrimonio e Industria, Spin-off University of Zaragoza, Zaragoza, Spain - j.angas@3dscanner.es \\ ${ }^{\mathrm{c}}$ Department of Geography and Spatial Management, University of Zaragoza, Zaragoza, Spain - <fcabello, delariva $>$ @unizar.es \\ d 3D Scanner Patrimonio e Industria, Spin-off University of Zaragoza, Postdoctoral Research Torres Quevedo (MINECO), Zaragoza, \\ Spain - manubea@unizar.es \\ ${ }^{\mathrm{e}}$ Department of Design and Manufacturing Engineering, University of Zaragoza, Zaragoza, Spain - serreta@unizar.es \\ ${ }^{\mathrm{f}}$ Department of Antiquity Studies, University of Zaragoza, Zaragoza, Spain- <amagallo, casaenz, mmartin>@unizar.es
}

\section{Commission V, WG V/4}

KEY WORDS: Aerial Mapping, UAV, Remote Sensing, multispectral image, NDVI.

\begin{abstract}
:
This report details the preliminary results of the research focused on Roman archaeological heritage in the Middle Ebro Valley (Spain). The principal objective of this project was to obtain several different readings by means of a UAV equipped with different sensors. Firstly, it has been possible to obtain accurate maps, 3D models and digital elevation models of the site. Secondly, it has been possible to investigate and define archaeological remains still underground, via a new methodology which utilises visible and near-infrared wavelengths.
\end{abstract}

\section{INTRODUCTION}

The aim of this study was to mitigate various problems currently encountered in the study of the archaeological site by applying remote sensing.

Currently, there is much that is unknown regarding urban and the architectural form of many of the buildings in these preRoman and Roman settlements. Given the economic inability to carry out archaeological excavations, low-altitude multispectral images were employed by UAVs (Unmanned Aerial Vehicles) or RPAS (Remotely Piloted Aircraft Systems) with the aim of investigating and defining the still-buried remains.

In recent years, various new technologies have emerged making it possible to obtain accurate data quickly at a lower cost in the field of archaeology.

Firstly, the reliability of UAVs and RPAS has rapidly improved, allowing archaeologists obtain accurate images in variable weather conditions. The possibilities offered to the field of archaeology by this emergent, cutting-edge technology is now generating great interest. Reflecting this interest are new scientific publications concerning the topic: Verhoeven et al. (2013), Hill (2013) o Eisenbeiss (2009) y Casana et al. (2014), to cite some examples.

Secondly, in parallel to UAV market, various types of software as Agisoft PhotoScan, Pix 4D and APS processes have improved mosaicing, orthorectification and image georeferencing, allowing the archaeologist to obtain a wide range of results such as accurate maps, 3D models or digital terrain and elevation models.

Likewise, the evolution of trade sensors (cameras) adapted for UAVs, above all those related to the field of precision agriculture, today allow the use of devices with a high spatial and a wide spectral resolution. Thus, it is possible to place multispectral cameras on these platforms, covering visible, near-infrared, SWIR and thermal (Casana et al. 2014) wavelengths, similar to those provided by satellite imagery. All these technological advances have been utilised in this project. Consequently, we present preliminary results in which the capabilities of this technique can be seen by their application in different types of deposits. Our aim was to discriminate between the possibilities of identification offered by remains buried beneath flat cultivated fields and steep orography with little vegetation, and the possibilities of identifying remains in unexcavated settlements.

\section{CASE STUDY}

The choice of the Middle Ebro Valley as geographical framework is due to the detection there of some of the oldest Roman structures in Hispania. This is the result of the crucial role played by this region in the Roman conquest of the Iberian Peninsula. Similarly, the Middle Ebro basin is a natural region with relatively well-defined geographical boundaries: the Catalan Coastal Range, the narrowing of the Riojan Valley, the Pyrenees and the Iberian mountain range.

According to Beltrán $(2006,218$ ), Rome would have had a recognized perception of this territory as an entity in Imperial times when Augusto created a judicial district - the juridical convent Caesauragustanus - which coincided almost exactly with this natural region, as is apparent from the Plinian description (Plin., Nat., 3.4.24.).

\footnotetext{
* Corresponding author. This is useful to know for communication with the appropriate person in cases with more than one author.
} 


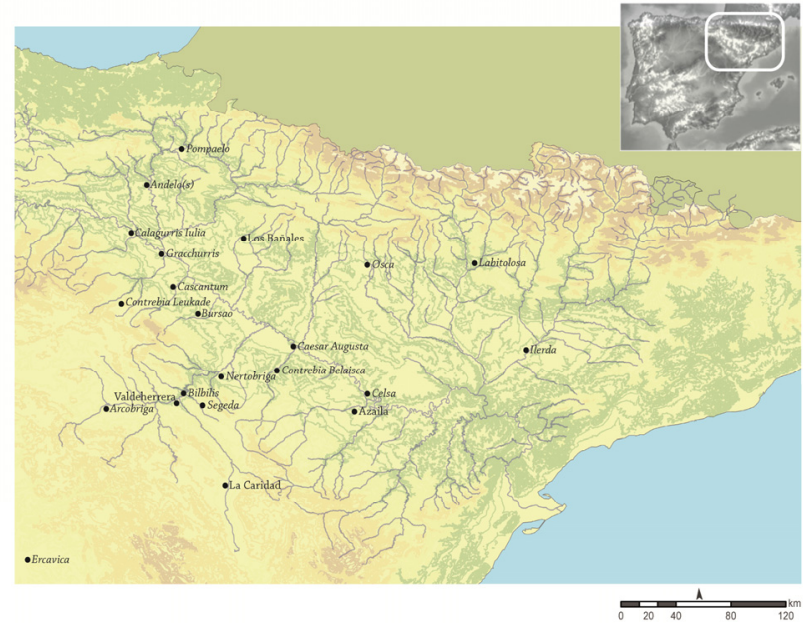

Fig. 1. Roman urban settlements in the Middle Ebro Valley (inhouse cartography).

Consequently, the object of our study covers the archaeological remains found in the current territory of Aragon. Among the many aspects of study offered by this territory, we can identify determined areas of interest in relation to the morphology, the chronology and current knowledge about the ancient settlements. The choosing of these fields has given us the opportunity to evaluate the method with the objective of examining its role in the assessment of the orography of sloping terrain, terrain with little vegetation and unknown sites.

The city of Valdeherrera, whose ancient name is unknown, was selected. This city is in the vicinity of Calatayud, to the southwest of Saragossa (Zaragoza), the ancient Caesar Augusta and capital of Conventus. In the northern zone we carried out a study in the pre-Pyrenean city of Labitolosa (La Puebla de Castro, Huesca). The city of Valdeherrera (Calatayud, Zaragoza) was located in one of the neuralgic points of Celtiberia between the confluence of the rivers Jiloca and Jalon. These rivers were two of the most important ancient natural routes, since they permitted rapid access to both the plateau and the coast (Sáenz and Martín-Bueno 2014, 206). Using terrestrial archaeological prospections, it has been estimated that the enclave would have covered around 40 hectares, of which 30 have survived. Although the name of the city is unknown, some authors have conjectured it was the location of the pre-Roman Bilbilis or the Platea mentioned by the famous Hispanic poet Martial (4.55.13; 18.12.11.). The oldest preserved remains date from the 4th and 5th centuries $\mathrm{BC}$ and had an important role in the Celtiberian Wars in the 2nd and 3rd centuries BC. The city would later be destroyed during the Sertorian conflict, surviving as a minor settlement in Imperial times. The ancient city was partially surrounded by a wide ditch to the East and South. It also had houses with central courtyards, decorated with opera signina pavements and walls in the First Style, as recent excavations have shown. These homes have been dated by their excavators as coming from the second half of the 2 nd century $\mathrm{BC}$.

The Hispano-Roman city of Labitolosa is located in Cerro del Calvario, the Ribagorzanan town located at the confluence of the rivers Cinca-Ésera some $2 \mathrm{~km}$ east of La Puebla de Castro, in the vicinity of Huesca. The original of the name Labitolosa was deduced from the Gentilic labitolosani that appeared in an inscription found in the 16th century, in a dedication made by the cives Labitolosani et incolae (CIL, II, 3008=5837). The recognition of Labitolosa as a Latin municipality was confirmed in 1994 by the discovery of an epigraph in the building of the municipal genius, located in the forum, which made an explicit reference to the municipality of Labitolosa (Navarro and Magallón 1999, 30-56). Thus the city, which originated in the late 1 st century $\mathrm{BC}$, developed into a stipendiary community and become a municipality during the Flavian period. In over twenty years of uninterrupted ${ }^{1}$ archaeological work in the city of Labitolosa, two complete thermal installations have been discovered, along with the remnants of several houses and a significant section of the forum, in which the Curia is particularly notable because of its epigraphic set.

\section{AERIAL MAPPING AND MULTISPECTRAL IMAGE}

The term UAV refers to an unmanned aerial vehicle that can be controlled remotely, its operation being either semi-autonomous or entirely autonomous. The use of this technology consists of the creation of a photogrammetric measurement platform that permits digitalization to obtain a 3D model of each one of the selected archaeological sites from aerial images. The necessary flight paths are pre-programmed, thus this particular platform operates autonomously. After takeoff, this UAV system is able to follow a programmed flight path over each site using preprogrammed GPS coordinates. The incorporation of highresolution calibrated RGB and NIR cameras allows the obtaining of high-resolution graphic models.

Although there are diverse types available today, an 8-engined UAV with a folding carbon structure - manufactured in-house was used in our project, with a Mikrokopter v. 2.02 ME flight control board. This system integration has been designed by Tecnitop SA together with the University of Zaragoza Department of Design and Manufacturing, which was enabled by the SME (Small and Medium Enterprise) Technology Transfer Program of the Aragonese Foundation for Research and Development. The project arose from the necessity of a platform capable of integrating particular sensors, in this case photogrammetric cameras already available in the research group but which could not be utilised with commercial systems. Two different sensors, that have allowed us to capture visible and near-infrared wavelength, have been used.

To capture visible wavelengths, an OLYMPUS E-PM2 ${ }^{2}$ - a micro four thirds compact camera with a 16-megapixel Live MOS sensor (max. resolution 17.2 megapixels) and TruePic VI processor - was used. This camera has a primary color (RGB) filter known as a Bayer filter. To capture near-infrared data, the Olympus E-PM1 ${ }^{3}$ (similar to the above-mentioned model), with a 4/3" sensor, was used. The micro $4 / 3$ was equipped with an 1inch diameter IR Long Pass optical filter produced by Edmund Optics. The sensitivity of the CMOS of the E-PM1 camera is between 300 and $1000 \mathrm{~nm}$, and the longitude range that the filter can capture is between 700 and $2250 \mathrm{~nm}$. This permitting us to obtain a radiation between 700 to $1000 \mathrm{~nm}$., with the

\footnotetext{
${ }^{1}$ Regarding the bibliography provided during these years of investigations, we refer to the recent monographic volume of the city: Magallón \& Sillières 2013.

${ }^{2}$ For more information, see:

http://www.olympus.es/site/es/archived_products/cameras_1/pe $\mathrm{n} \_$1/e pm_2/index.pdf

${ }^{3}$ For more information, see:

http://www.olympus.es/site/es/archived_products/cameras_1/pe n_1/e_pm1/index.pdf
} 
radiation being absent or very low, between 300 and $700 \mathrm{~nm}$. This type of sensor has already been applied in aircraft by Verhoeven $(2008 ; 2012)$.

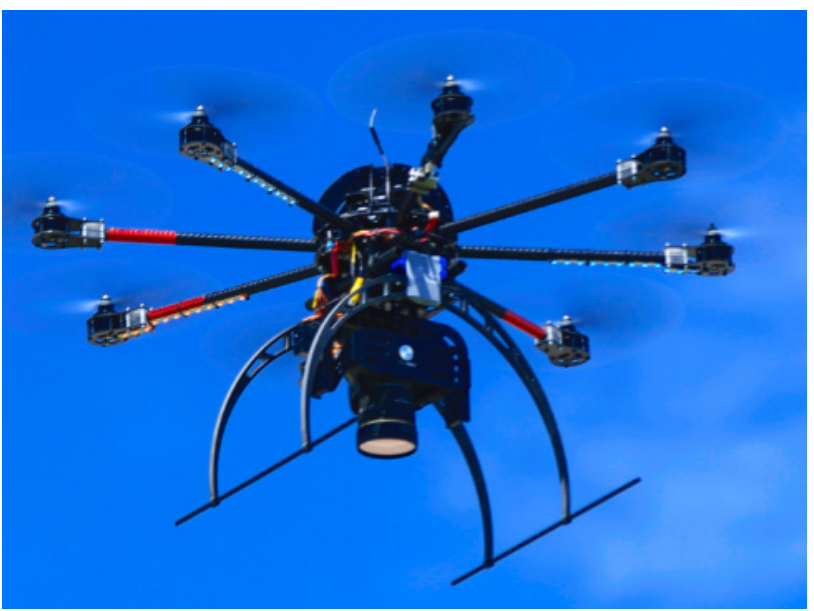

Fig. 2. Example of a generic UAV prototype (Unmanned Aerial Vehicle) used in this project.

\section{DATA ACQUISITION}

The acquisition of field data requires the determination of several control points on the ground, known as GCPs (Ground Control Points). This acquisition required a good geometric distribution within the defined flight area with the objective of scaling the final model to a metric system, and inserting it into the selected coordinate reference system. In both tasks, the geodetic reference system used was the official system of Spain - UTM ETRS89 (Royal decree 1071/2007 of 27 July) - in UTM zone 30. The GCPs were acquired using a Leica GS14 GNSS system. In Valdeherrera, the GNSS system was connected via radio link to the geodesic IGN vertex 43756 (Valdegalindo), located in the municipality of Paracuellos de Jiloca. In Labitolosa, the connection between the mobile equipment to a fixed network was carried out via GPRS connection to the ARAGEA active geodesic network of the Aragonese Government (http://gnss.aragon.es/). Subsequently between 15 and 20 points, distributed within the defined area, were recorded. Landmarks ranged from easily-identified points in the field, such as roads or stones, along with targets and survey stakes in areas with vegetation. Consequently, a file with the format "x, y, z, cod" was obtained, to permit later photogrammetric support. The flights in both cases, Valdeherrera and Labitolosa, were planned using the MKTools application. The purpose of this planning was to define a route that would allow a longitudinal and transverse image overlap of $80 \%$. The average speed for both flights was $10 \mathrm{~m} / \mathrm{s}$ at an altitude of approximately 100 metres. The images were recorded in a .raw format (the proprietary Olympus format being .orf) with the same fixed Zuiko Digital ED $12 \mathrm{~mm} \mathrm{f} / 2.0$ lens with an ISO of 200 and with a manual focus to infinity. In Valdeherrera the images were obtained on the 7th July 2013 between 12 noon and 2:00 pm. In Labitolosa the same schedule was used, but the images were acquired on October 5th, 2014.

\section{IMAGE PROCESSING}

The orthorectification and mosaicing processed were performed by Agisoft PhotoScan (2014) software, for all wavelengths. The data processing is summarised in the following steps:

1. Importation of selected images.

2. Synchronization of pictures, coordinates and angles (yaw, pitch, roll).

3. Alignment of images using bundle adjustment or common points.

4. Importation of the .txt file with the acquired GCPs.

5. Recognition of the images of the GCPs and $\mathrm{x}, \mathrm{y}, \mathrm{z}$ error control.

6. Adjustment of the layout, selection of the coordinate system used and triangulation of the point cloud.

7. Application of the texture of each of the images that make up the $3 \mathrm{D}$ model using a radiometric adjustment by Adaptive Orthophoto ${ }^{4}$.

8. Exportation of errors in the model, point cloud, 3D model, orthophotos and elevation map.

After obtaining the orthophotos and 3D models, the data was adapted to work with Erdas Imagine (2013). This adaption consisted of the creation of a layer stack with the VIS and the NIR images in .tiff format, generating multilayer files with 6 bands of multispectral information in each case. (VIS = 123; $\mathrm{NIR}=456$ ).

For the identification of buried archaeological remains the following techniques of digital image processing have been applied in combination: (a) the generation of new bands of information (neo-channel and PCAs) from the original bands; and (b) the application of radiometric and spatial enhancements and the creation of compositions in false color (RGB), applied both to the original bands as well as the neo-channels.

a) The generation of neo-channels allows us to extract continuous information and enhance significant aspects of the images from the original bands. For this study the metric relationship between bands has been employed to estimate biophysical parameters such as plant vigor, in the case of obtaining vegetation indices, and the statistical relationship between bands to create the Principal Component Analysis (PCA).

The vegetation indices consist of the pixel-by-pixel building of ratios or quotients, between the digital levels of two or more image bands (Chuvieco 2010, 337). Specifically, for this project have been used: NDVI (Normalized Difference Vegetation Index, Rouse et al., 1974), Green NDVI (Green Normalized Difference Vegetation Index, Gitelson et al., 1996) y Soil Adjusted Vegetation Index (SAVI) (Huete, 1988). The potential of this technique in the field of archaeology and was raised by Verhoeven and Doneus (2011), Verhoeven (2012) y Bennett et al. (2012).

The PCA (Principal Components Analysis) is a statistical procedure that reduces redundant information by transforming a number of quantitative variables (common underlying dimensions) into a number of new uncorrelated variables. This reduction is performed using a variance-covariance matrix

${ }^{4}$ To create the texture of the 3D model, the software performs a radiometric adjustment based on the average of each pixel in each image taken. 
without losing significant portions of the original information. This capacity of synthesis is of great interest in the field of remote sensing as the acquisition of images in adjacent spectrum bands often involves the detection of redundant information, since canopy cover often exhibit similar behavior in close wavelengths. In the field of archeology, it has been used in particular when working with hyperspectral sensors (Traviglia 2006). In this work, it has been applied to the VISNIR image (containing all six bands) for the creation of neochannels.

b) With respect to radiometric and spatial enhancements, radiometric histogram adjustments, compositions false color (RGB) and spatial filters have been applied. According to Jensen $(1996,145)$, the linear contrast tends to expand the original digital levels to the minimum and maximum (0-255) to exploit the sensitivity of the device. In this case, statistical (standard deviation) thresholds were used, which were defined statistically and interactively using breakpoints. These settings have been applied to the following images and neo-channels: VIS, NIR, and VIS-NIR images, NDVI neo-channels, Green NDVI, SAVI and ACP. False color compositions are three-band combinations, to each of which were assigned additive primary colors (Red, Green and Blue -RGB-). Here, in place of the original bands, the three NDVIs (those created with the three bands of NIR, vid. infra), or the six ACP bands, have been used.

Filters or spatial enhancements are based on the concept of spatial frequency - that is, the number of changes in the brightness per unit of distance (Jensen 1996, 153). These seek to strengthen or weaken spatial contrasts between adjacent pixels via the use of a mobile matrix of filtering coefficients, or kernel. Two types of filters can be distinguished by their filtering coefficients. Firstly, low-pass filters, that have a tendency to highlight the homogeneity component of the image, thereby softening it. Secondly, high pass filters, which sharpen the contrasts between the digital levels of adjacent pixels, leading us to believe they could act as effective tools for the detection of structures. Thus they have been applied to the following images: VIS, NIR, VIS-NIR, as well as individual images without orthorectification or mosaicing. Lasaponara and Masini $(2012,51)$ describe this type of image processing for archaeological remote sensing using satellite imagery.

\section{RESULTS}

While the timing of data acquisition was not optimal, due to the phenological time of the vegetation (the images of Valdeherrera were taken in July), a series of structures in the Roman city of Valdeherrera have been identified (figs. 3 and 4) (Fig. 3 y Fig. $4)^{5}$.

\footnotetext{
${ }^{5}$ The archaeological findings of Labitolosa (Huesca) have not been included as they are still in the processing phase (the field data was collected in October 2014). However, we note that, applying the same methodology used in the case of Valdeherrera, initial results have been obtained.
}
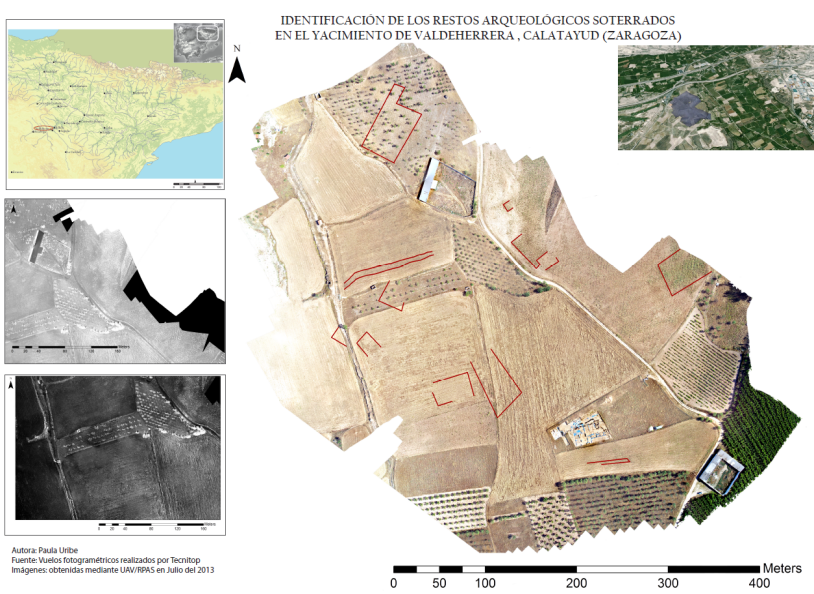

Fig. 3. Mapping with the results obtained for the Valdeherrera site (VIS image).

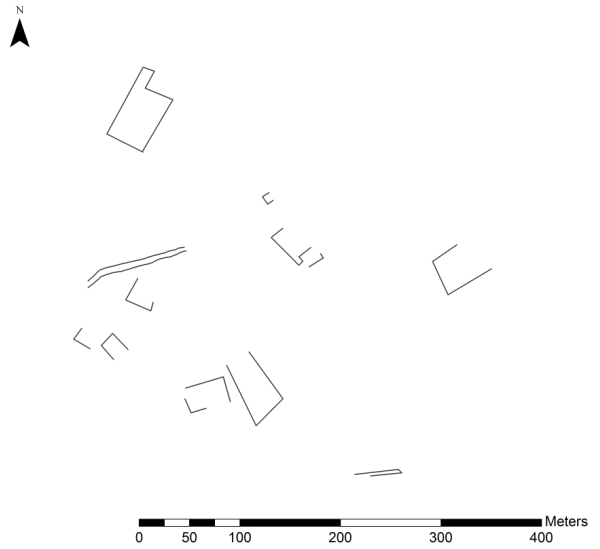

Fig. 4. Documented archeological remains at the site of Valdeherrera (VIS image).

Of the structures identified, we focus on the structure known as A (figs. 5 and 6). We believe it delineates an important building in the city due to its elevated position (as shown in the Digital Elevation Model), its dimensions $(25 \times 26.67 \mathrm{~m})$ and the discovery of large rectangular ashlars on the ground.

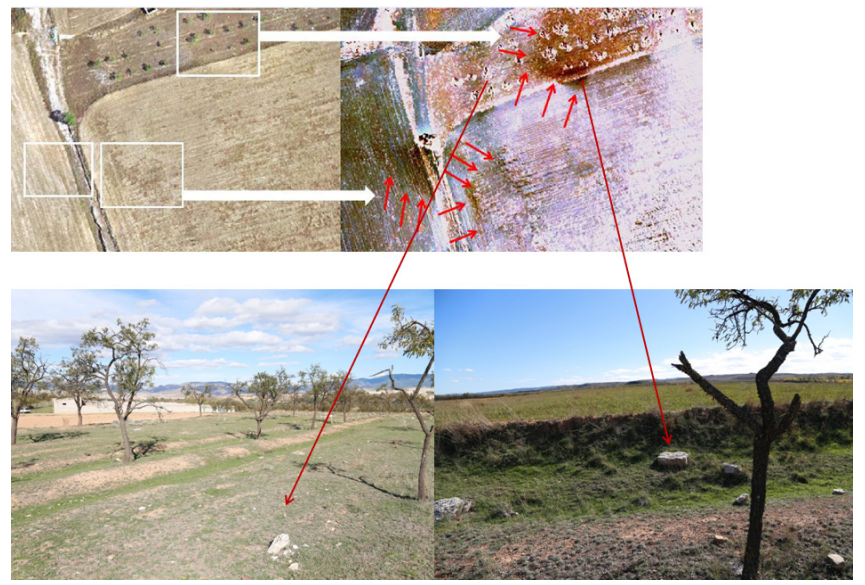

Fig. 5. Documentation of rectangular ashlars on the ground that confirm the existence of a structure. 


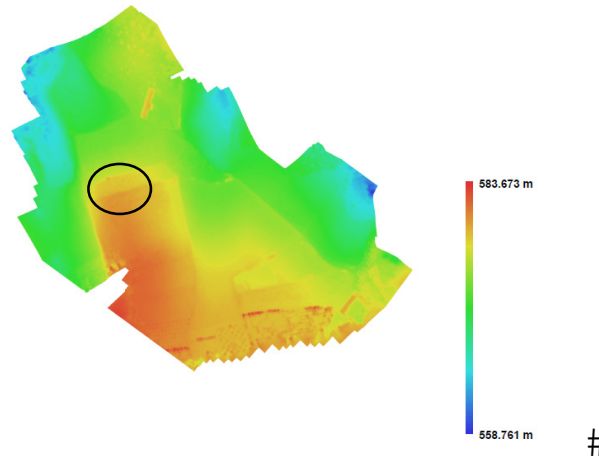

Fig. 6. Digital Elevation Modelo (DEM) with the location of structure A.

Similarly, with the structure we identify as B (fig. 7), we posit that it delineates a large structure well-located in the river basin. From its form and dimensions $(40 \times 20 \mathrm{~m}$.) we believe it was one of the entrances to the city.

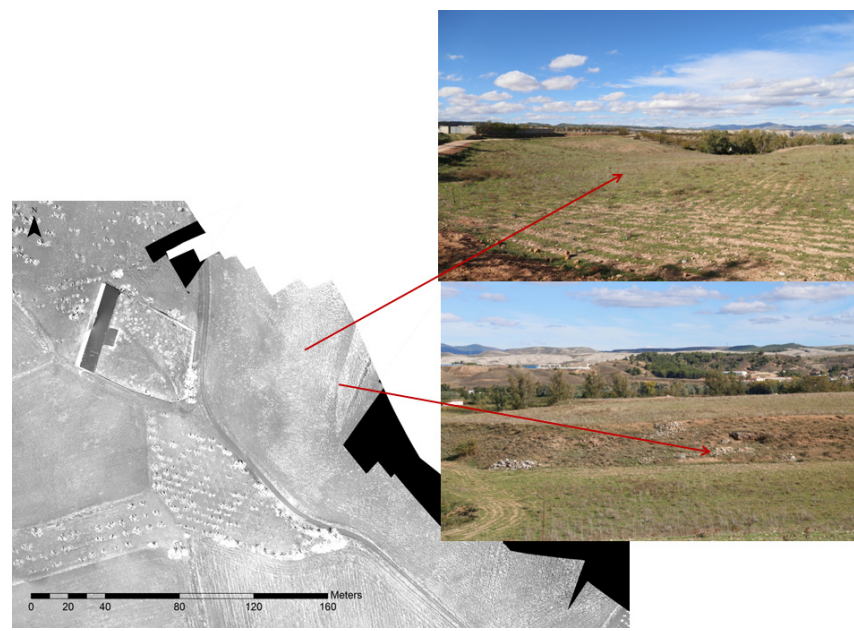

Fig. 7. Archaeological remains on the ground that confirm the existence of a structure B.\#

Figure 8 shows the results of a linear contrast enhancement using breakpoints. Its application to vegetation indices has been that which has provided the best results - the clear visual definition of underground structures -. As can be observed in the results obtained by linear contrast enhancement (fig. 8), the digital levels corresponding to the remains are distributed at the extremes of the histogram, being either extremely dark or extremely light.
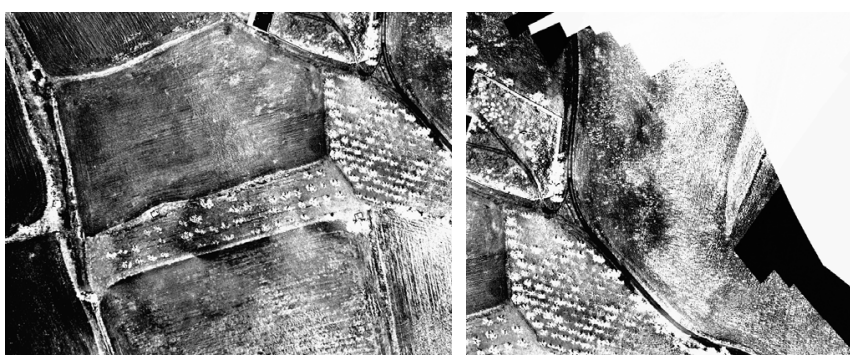

Fig. 8. Detail of the result of the linear contrast enhancement of the histogram with breakpoints of images NDVI_5 and NDVI_6 of Valdeherrera.
As discussed in the section on methodology, it was initially thought that high-pass filters could be effective tools for the detection of structures. However, as shown below in Figure 9, the results have not been optimal for the purposes of this work.

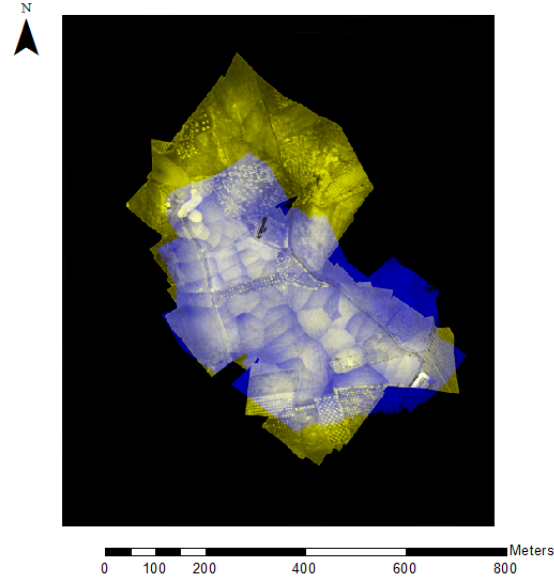

Fig. 9. Results of the digital processing of the VIS-NIR image of Valdeherrera. The filter used was high-pass, with a $5 \times 5$ kernel (composition 643) with a standard deviation linear contrast enhancement of 2.5 .

As shown in the above image (fig. 9) the results obtained with these tools were not as hoped. The PhotoScan mosaicing process is reflected in the image after applying a $5 \times 5$ high-pass filter. We have observed that by reducing the kernel to $3 \times 3$, this does not occur. In this way, the $5 \times 5$ high-pass filter digital processing has been used as a tool for discriminating the buried residues in the overlapping of the PhotoScan images, becoming a necessary tool for the processing of the results given by the mosaicing.

The process of determining the Principal Components has not been particularly revealing, identifying practically the same archaeological remains as with vegetation indices, as shown in the detail image above (fig. 10). However, the process vastly improves the identification of archaeological remains when using the PCAs displayed using false color compositions.

Likewise, the use of the vegetation indices (figs.11 and 12) to display underground structures shows itself to be a suitable tool with high potential ${ }^{6}$.

\section{$\hat{A}$}

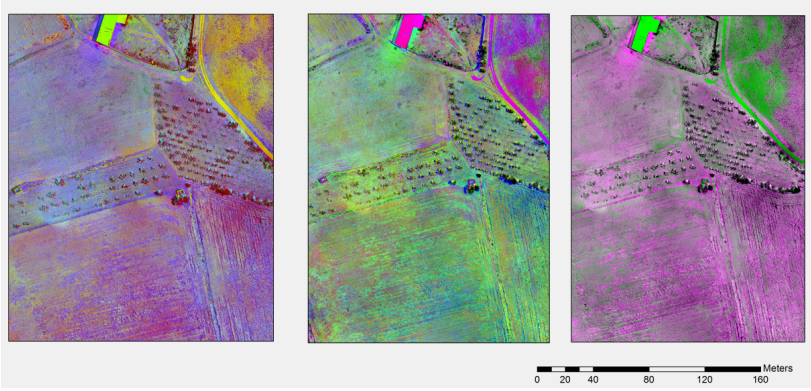

${ }^{6}$ Acording to the NDVI application to identify archaeological remains, vid: Lasaponara y Masini (2006); Verhoeven and Doneus (2011); Lasaponara y Masini (2012); Verhoeven (2012); Bennett et. al (2012). 
Fig. 10. Display using false color compositions of the results obtained from the PCA. The first image combines the PCA 123; the second 234, and the third 323. The three images were processed with standard deviation enhancement of 2.5 .

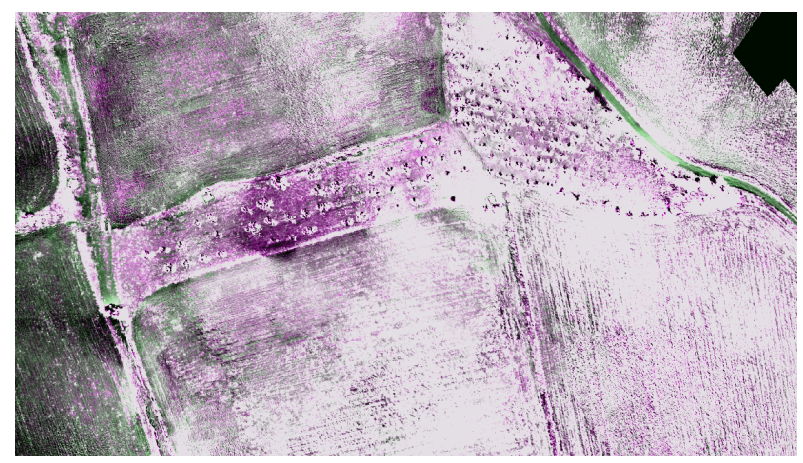

Fig. 11. Detail of false color composition with the three NDVIs (R: NDVI_6; G: NDVI_5; B: NDVI_6) and linear contrast enhancement of the histogram with breakpoints in Valdeherrera.

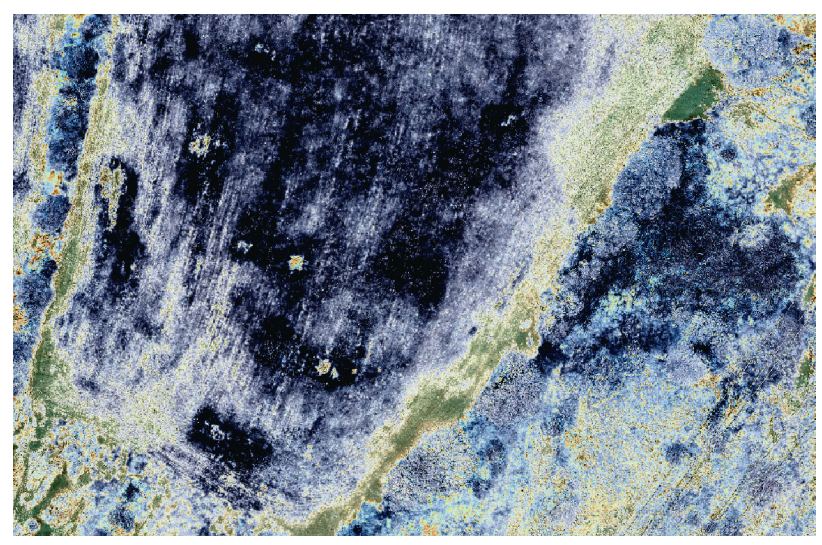

Fig. 12. Detail of false color composition with the three NDVIs (R: NDVI_6; G: NDVI_5; B: NDVI_6) and linear contrast enhancement of the histogram with breakpoints in Labitolosa.

\section{CONCLUSIONS AND PROSPECT}

In conclusion, it can be seen that the use of UAVs in the field of archeology, primarily, reduces costs. The acquisition of a very high-resolution commercial satellite image or the carrying out of a manned flight greatly increases the cost of fieldwork. Secondly, it is possible to obtain custom data, where the researcher defines the pixel resolution required for the project, and also obtains mapping results: drawings, 3D models, and digital terrain and elevation models. In the same way, the incorporation of multispectral sensors permits the visualization of elements beyond visible wavelengths, that the human eye is incapable of detecting. This, however, introduces a new set of problems such as orthorectification and the processing and obtaining of images.

Despite these problems, and based on the results, it has been proved that this methodology is optimal for identification of buried archaeological remains. After reaching this conclusion, there are many issues concerning future work:

- Without doubt, it has been demonstrated that UAVs, in this day and age, are highly effective in remote sensing studies requiring a maximum spatial resolution tool. However, particular aspects remain to be developed sufficiently, such as: flight time, compatibility with particular sensors, and the integration of RTK GNSS receivers to eliminate the need of support topography. We feel that this area, which is under development, will offer in next years to come more stable and innovative solutions such as the possibility of the use of 3D laser scanners on such aerial platforms.

- Experimentation with different sensors is still required. A new sensor, the Tetracam Mini-MCA6 has been available since October 2014. The various approaches taken with this camera (the results of which are still under study) have shown that the management of such approaches is not simple, as many problems surface, such as orthorectification and mosaicing. Consequently, we feel, although the precise ranges of wavelengths is unknown, the use of the Olympus E-PM2 and EPM1 cameras is currently the most effective and inexpensive method for reaching our archaeological objectives.

- With respect to image treatment, normalized vegetation indices and their subsequent treatment have proved to be the most effective for our purposes. The use of filters has allowed us to discriminate the mosaicing effects of Agisoft PhotoScan. However, other techniques, such as ACP, have produced relevant results when visualised in false color compositions. Thus several lines of research remain open, such as the deepening of the discrimination of soil marks or zonification of the vegetation index pixels.

In conclusion, we believe that the results have been satisfactory. From an archaeological perspective, despite subsequent checks in the field, only the archaeological excavation of documented structures can validate our method and hypothesis.

\section{ACKNOWLEDGEMENTS}

This research is included within the project led by Dr. M. Martín-Bueno: (HAR2013-48456-C3-1-P) URBS: Public and private ornamental repertoires in NE Hispania, funded by the Ministry of Economy and Competitiveness and Dra. Ma. A. Magallon (HAR2011- 24390) - Roman Hydraulics in the Middle Ebro Valley II. The Roman dams of Muel (Zaragoza), Pared de los Moros (Muniesa. Teruel) and Virgen del Pilar (Moyuela, Teruel) Ministry of Economy and Finance.

We would like to thank Tecnitop and the Spin Off project Scanner Patrimonio e Industria for all its support and help during the post-processing of the images.

\section{REFERENCES}

Angás, J., Uribe, P. 2012. Social spreading of geometric, recorded data from a range of types of 3D scanners via a web data server, Archaeology in the Digital Era Volume II, 40th Conference on Computer Applications and Quantitative Methods in Archaeology, Southampton, pp. 363-375.

Barrientos, A., del Cerro, J., Gutiérrex, P., San Martín, R. Martínez, a. y Rossi C. 2007. "Vehículos aéreos no tripulados para uso civil. Tecnología y aplicaciones" http://webdiis.unizar.es/ neira/docs/ABarrientos-CEDI2007.pdf

Braasch, O. 2007. "Gallipoli Ahead-air survey between the Baltic and Mediterranean" In: Publikácia vznikla v rámci Centra excelentnosti SAV Výskumné centrum Najstarsich dejín Podunajska pri Archeologickom ústave SAV, Nitra, pp. 84-96. 
Bennett, R., Welham, K., Hill, R. A. y Ford, L. J. 2010. The application of Vegetation Indices for the prospection of Archaeological features in grass-dominated Environments, Archaeological Prospection, 19, pp. 209-218.

Beltrán, F. 2006. El valle medio del Ebro durante el periodo republicano: de limes a conventus, In: La invención de una geografia de la Península Ibérica, Málaga-Madrid, pp. 217240.

Campana, S. 2011. Remote Sensing, GIS, GPS e tecniche tradizionali. Percorsi integrati per lo studio dei paesaggi archeologici: Murlo-Montalcino e bassa Val di Cornia. Tesi di Dottorato. https://cambridge.academia.edu/StefanoCampana

Casana, J., Kantner, J., Wiewel, A. and Cothren, J. 2015. Archaeological aerial thermography: a case study at the Chacoera Blue J community, New Mexico, Journal os Archaeological Science, 45, pp. 207-219.

Chuvieco, E. 2010. Teledetección ambiental. La observación de la tierra desde el espacio, Ariel Ciencia, Barcelona.

Doneus, M., Verhoeven, G., Atzberger, C., Wess, M. y Rus, M. 2014. New ways to extract archaeological information from hyperspectral pixels, Journal of Archaeological Science, 52, pp. 84-96.

Eisenbeiss, H. 2009. UAV Photogrammetry, Zurich, Phd. http://www.igp-

data.ethz.ch/berichte/blaue_berichte_pdf/105.pdf

Eisenbeiss, H. y Zang, L. 2006. Comparison of DSMs generated from mini UAV imagenery and terrestrial laser scanner in a cultural heritage application, International Archives of the Photogrammetry and Remote Sensing, 36 (5), pp. 90-96.

Erdas Imagine 2013. Erdas Imagine 2013. Huntsville, AL: Intergraph Geospatial

GMES Initial Operations emergency mapping validation service. Technical Specifications JRC/IPR/2012/G02/007/OC, JRC - European Commission.

Gitelson A. A., Kaufman Y.J., Merzlyak, M. N. 1996. Use of green channel in remote sensing of global vegetation from EOS-MODIS, Remote Sensing Environment 58, pp. 289-298.

Hill, A. C. 2013. UAVs at Marj Rabba, In: Israel: low-cost high-tech tools for aerial photography and photogrammetry. Society for American Archaeological Record 13 (1), pp. 25-29.

Huete, A. R. 1988. A soil-adjusted vegetation index (SAVI), Remote Sensing Environment, 25, pp. 295-309.

Jensen, J. 1996. Introductory digital Image processing, Prentice Hall Series in Geographic Information Science, Prentice-Hall Inc., Upper Saddle River, New Jersey.

Lasaponara, R. y Masini, N. 2012: Satellite Remote Sensing A New Tool for Archaeology, Springer, New York.

Magallón, M. A. y Sillières. P. 2013. Labitolosa une cité romaine de 1'Hispanie Citérieure, Insitut Ausonius Col. Mémoires nº 33, Burdeos.

Martín-Bueno, M., Sáenz, C., Krausz, S. y Mathé, V. 2009. La ciudad celtibérica de Valdeherrera (Calatayud, Zaragoza). Prospecciones geofísicas, Salduie, 9, pp. 419-439.

Montero Ruiz, I.; Rodríguez Alcalde, A. L.; Vicent García, J. M., y Cruz Berrocal, M. 2000. Técnicas analíticas basadas en el proceso de imágenes digitales multiespectrales, Arkeos, 7. pp. $13-34$.

Nagy, P., Unold, W. and Vogt, S. 2001. Flug in die Vergangenheit. Die Luftbildpropektion im Dienste der Arhaeologie, Helvetia Archaeologica, 125/126, Zürich.

Navarro, M and $\mathrm{M}^{\mathrm{a}}$. A. Magallón, 1999. Las ciudades del prepirineo occidental y central en época alto-imperial: sus habitantes y su status" In: Simposio Internacional de Epigrafia E. I. E. G. L. Ciudades privilegiadas en el Occidente Romano, Sevilla, pp. 30-56.

Rejas, J. G. et al. (forthcoming). Anomaly Detection using remote sensing for the Archaeological Heritage registration, Digital Heritage Congress, Marsella.

Rouse, J. W., Hass, R. H., Schell, J. A., Deering, D. W. 1974. Monitoring vegetation systems in the Grat Plains with ERTS. In : Proceedings Third Earth Resources Technology Satellite-1 Symposium, Greenbelt, NASA SP-351, pp. 309-317.

Sáenz, C. and Martín-Bueno, M. 2012. La ciudad celtibérica de Valdeherrera (Calatayud. España), Aquitania, 28, pp. 7 - 32.

Sáenz, C. and Martín-Bueno, M. 2014. Valdeherrera: la ocupación del territorio en época celtibérica en el valle medio del Jalón, In : La guerre et ses traces. Conflits et sociétés en Hispanie à l'époque de la conquête romaine (IIIe-Ier s. a.C.), Burdeaux, pp. 213-229.

Traviglia, A. 2006. Archaeological usability of hyperspectral images: successes and failures of images processing techniques, In: From Space to place. Proceedings of the 2nd International Conference on Remote Sensing in Archaeology, Roma, pp. 123130.

Verhoeven, G. 2008. Imaging the invisible using modified digital still cameras for straightforward and low-cost archaeological near-infrared photography, Journal of Archaeological Science, pp. 3087-3100.

Verhoeven, G. 2012. Near_infrared aerial crop marks archaeology: from its historical use to current digital implementations, Journal of Archaeological Method and Theory, 19 (1), pp.132-160.

Verhoeven, G., Doneus, M., Atzberger, C., Wess, M., Rus, M., Pregesbauer, M. y Briese, C. 2013. New approaches for archaeological feature extraction of airborne imaging spectroscopy data, In: Archaeological prospection. proceedings of the 10th International Conference on Archaeological Prospection, pp. 13-15. 